\title{
MODERN TRENDS IN MINIMISATION OF OFFSHORE JURISDICTION: OECD, G20 AND RUSSIA
}

\author{
G.Korolev, A.Levashenko
}

For many years, off-shore zones were a reliable mechanism of tax optimization. According to experts' estimates, Russia is the world's leader as regards the number of newly registered off-shore companies ${ }^{1}$. For the purpose of effective prevention of erosion of the tax base, Russia should join not only the OECD standards, but also that international organization, as well.

Off-shore zones can be classified by various criteria: the level of transparency (the extent of openness of the tax /banking data), the level of taxation (a zero taxation or simplified taxation), lines of activities of companies incorporated more often in the particular off-shore zone (shipping, commercial, insurance business and other), countries whose residents use more often this or that off-shore zone (territorial belonging of the off-shore zone) and the type of law under which the legislative system of the particular off-shore zone is built.

It is important to single out off-shore zones which are "classical" jurisdictions and countries which have the offshore specifics. The first type of off-shores includes such countries as Panama, the British Virgin Islands, the Bahamas Islands and other states where there are no taxation and requirements to submit forms of accounting statements to tax authorities, the procedure for registration of entities is simplified, registration is carried out within the shortest period of time and presence of the direct founder of the company is not required.

The second type of off-shore zones includes countries or administrative units of countries with the specifics of the offshore jurisdiction (Cyprus, Switzerland, Hong Kong, Singapore, Panama, Malta and other) where there are a simplified procedure for incorporation of entities, but, sometimes, quite an expensive one (as, for example, in Switzerland), taxation and the need to submit accounting statements to tax authorities. Some of those countries are members of prominent international organizations (the WTO and the OECD) or integrated territorial unions (for example, the EU).

Along with that, there are four main groups of offshore zones formed on the basis of the regional principle. The global network of offshore centers is unevenly distributed by the continents: seven of them as situated in North America, 25 in Southern and Central America, 28 in Europe, 19 in Asia, 7 in Africa and 14 in Oceania.

1 See: A.A. Yakovlev. The Criteria of Attribution of Territories and Jurisdictions to Offshore Zones // Your Tax Lawyer. 2008. No. 11.
At the same time, governments could not leave the fact of tax evasion unnoticed and by means of intrastate measures and mechanisms of interstate cooperation (in particular with assistance of the OECD) coordinate their policies as regards minimization of the impact of offshore jurisdictions on erosion of the tax base due to which budgets experience tax losses. Among countries, there is no unified approach to the issue of control over offshore zones. The US, Japan and Switzerland regards tax competition both as an instrument of dealing with inefficient public expenditures and the one of effective placement of business activities. It is to be noted that most EU and OECD member-states use different methods of fighting tax competition by determining the international tax harmonization as a priority line of their activities. What is meant here is such a system of measures to bring in harmony the tax policy of countries which are member-states of different unions or associations as consist in adjustment of tax rates in different states and elimination of double taxation. According to the EU and the OECD, tax competition results in a situation where different aspects of direct and indirect taxation actually become a new area of competition on the intergovernmental level, including that in terms of development of innovations, and a major factor of economic development in some regions, in particular, recognized offshore zones, that is, it leads to an upset of the international economic balance.

In Russia, there are two main documents which determine the lists of countries with the offshore specifics. It is Order No.108 of November 13, 2007 of the Ministry of Finance of the Russian Federation and Instructions No. 1317-U of August 7, 2003 of the Central Bank of the Russian Federation. In respect of those jurisdictions, a tax privilege of $0 \%$ on proceeds received by Russian entities as dividends is not applied provided that certain conditions are met. At the same time, despite those documents which clearly determine the list of offshore jurisdictions the Supreme Arbitration Court of the Russian Federation (SAC RF) formulated its stance on that issue in its ruling of March 26, 2013 
on case No. $14828 / 12$ TSZh Skakovaya 5 vs. OOO Arteks Coorporation. The Supreme Arbitration Court of the Russian Federation ruled that courts were in a position to attribute individually a foreign state in which a legal entity was incorporated and which legal entity took part in arbitration proceedings to offshore jurisdictions. In addition to the above, offshore companies participating in arbitration proceedings have to provide the court with the information on beneficiaries, affiliated persons and the corporate structure. If such information fails to be provided the court may recognize as the proved ones the circumstances in favor of the adverse party and on the basis of that deliver a judgment against the offshore company. Such is the stance of the Russian judicial system. After the planned merger of the Supreme Court of the Russian Federation with the Supreme Arbitration Court of the Russian Federation the above legal position will remain unchanged as minimization of the impact of offshore jurisdictions is an objective of the state policy ${ }^{1}$.

As regards international cooperation, it is worth mentioning the G20 Summit in St. Petersburg last summer where participants approved by a majority of votes the OECD Plan of Actions to Prevent Erosion of the Tax Base and Non-Disclosure of Profits' ${ }^{2}$, that is, a measure aimed against offshore jurisdictions. Also, the above Plan sets the deadlines of implementation of the proposed measures, that is, they are to be realized within two years.

Participants in and associated members of the OECD recognize that the existing system of bilateral international double taxation treaties is imperfect, so, fundamental changes which permit to eliminate such legal gaps and conflicts as make it possible to evade taxation are required. The Plan is primarily focused on information technologies in tax administration, in particular, an automatic exchange of information on taxpayers. So, to receive the information on beneficiary companies an official request is not needed and the information is automatically provided by a member-state. As regards that above, the OECD will cooperate with G20, the World Bank and all the interested parties, particularly, as regards assistance to developing countries on that matter. Also, the em-

\footnotetext{
1 In particular, in the President's State of the Nation Address of December 12, 2013 to the Federal Assembly it is stated that revenues of companies incorporated in offshore jurisdictions and owned by a Russian national - the ultimate beneficiary - are to be taxed in accordance with Russian tax rules and tax payments paid to the Russian budget. Companies incorporated in a foreign jurisdiction are not allowed to use state support measures, including loans of the Bank for Foreign Economic Affairs and state guaranties. Such companies are to be denied access to fulfillment of state contracts and contracts of entities with state participation.

2 Action plan on base erosion and profit shifting. OECD. 2013.
}

phasis was made on the efficient exchange of information in the Annex to the Declaration of the G20: the number of jurisdictions which assumed obligations as regards introduction of standards and joined the global forum on the exchange of information for tax purposes increased to $120^{3}$. By the end of 2015, G20 member-states are expecting to start an automatic exchange of information in the sphere of taxation. In addition to that, it is stated in that document that "the Multilateral Convention [the OECD convention on mutual administrative assistance in taxation issues] is of key importance to a prompt introduction of a new standard and ensuring of advantages of a new more transparent system to developing countries". By the middle of 2014, it is expected to complete the work on technical aspects of an effective automatic exchange of information.

In May 2013, the UK overseas territories (Anguilla, the Bermuda Islands, the British Virgin Islands, Montserrat and the Turks and Caicos Island) joined the system of an automatic exchange of information with such states as the US, Spain, Germany, Italy and France $^{4}$. Also, the Isle of Man, Guernsey, Jersey and Gibraltar joined the system. Establishment of that system was the result of efforts by the US government in the frameworks of the Foreign Account Tax Compliance Act (FATCA). So, under the impact of new trends low-taxation jurisdictions which remained in high demand in the past few years became participants in the fight against offshore zones.

However, not all the OECD member-states approved that initiative. For instance, Switzerland definitely stood against the automatic exchange of information.

The required measures are related to neutralization of conflicts of law principles of various regulatory acts in the tax sphere: norms of intrastate legislation and international bilateral double taxation treaties. To achieve that, it is planned to utilize provisions both of the OECD model tax convention in respect of revenues and capital and respective guidelines, for example, those for limited application of tax deductions and utilization of harmonized rules in respect of affiliated persons.

In the plan of actions, it is stated that the received income is to be more accurately linked to the economic activity which has generated it. Imperfection of the existing system is a factor behind many abuses by taxpayers of provisions of bilateral double taxation treaties.

3 The Annex on the issues of taxation to the Declaration of the Leaders of G20 States. September, 2013.

4 Chancellor welcomes huge step forward in global fight against tax evasion. HM Treasury. Published 2 May 2013 // https://www. gov.uk/government/news/chancellor-welcomes-huge-step-forward-in-global-fight-against-tax-evasion 
The plan of actions approved at the G20 Summit in St Petersburg provides for tough deadlines for implementation of those measures (that is, within the period of two years). So, offshore zones in a normal definition of that term will be liquidated in the near future.

The need of liquidation is justified by a few factors. During the financial and economic crisis of 2008, many countries started to look for additional sources of budget revenues. In most states, a territorial principle of taxation is used. Under the above principle, taxes are charges at a source of revenues in the territory of a respective state. So, a transfer of assets to other jurisdictions poses a threat to budget revenues of states where the above principle is utilized. As a consequence of the first proposal, at the level of the international and legal regulation of tax policies of states a more efficient cooperation in bringing taxation rules and norms into harmony emerged. It is likely that the experience of EU member-states will be used as the standard of harmonization and networking. Countries cooperate for the purpose of minimization of a harmful tax competition and liquidation of conflicts of laws. The existing system of double taxation treaties does not permit to avoid completely such conflicts of laws.

In Russia, a fight against offshore zones is complicated due to a few factors. Firstly, there is no agreement on the exchange of information with most lowtaxation jurisdictions ${ }^{1}$. At the same time, Russia does not actually maintain an adequate exchange of information with tax authorities of foreign states. Affiliation of persons has not been determined (for more than a year from April 3, 2012 till the present day relevant regulations have been at a draft law stage $\left.{ }^{2}\right)$. Secondly,

1 Russia does not have an agreement with the following jurisdictions: Panama, the Isle of Man, Gibraltar, Malta, the Seychelles Islands, the British Virgin Islands, Nevis, the Bahamas Islands, Liechtenstein, Hong Kong, the Channel Islands (Jersey and Guernsey), Uruguay and the Cayman Islands.

2 http://asozd2.duma.gov.ru/main.nsf/\%28SpravkaNew\%29?O penAgent\&RN=252441-6\&02 for the purpose of efficient prevention of erosion of the tax base, Russia should join as soon as possible the OECD - the organization which has the ultimate influence in a fight against offshore zones. In addition to the above, it is the OECD that develops and introduces effectively the standards of fight against optimization of taxation by means of low-taxation jurisdictions. Thirdly, Russia's participation in the Customs Union and the Single Economic Space with countries which are not and cannot be member-states of the OECD or G20 in the near future may weaken to some extent the fight against offshore zones. The single customs territory, common external borders and free flow of goods, services and capital requires coordinated actions by Russia, Kazakhstan and Belarus to carry out an effective tax administration both in respect of third countries and between one another. So, offshore schemes can be realized through other member-states of the Customs Union - Belarus and Kazakhstan - provided that they do not carry out fight against offshore zones (for example, unlike Russia they may not have an agreement on exchange of information with tax havens). Consequently, by virtue of the existence of the national regime between the three countries all the member-states of the Customs Union should adopt common rules in respect of offshore zones and contribute to uniformity of enforcement procedures in that regard. In addition to the above, Russia, Kazakhstan and Belarus have to ensure between one another an effective exchange of information on tax issues, as well as banking information. Also, member-states of the Customs Union and the Single Economic Space should carry out simultaneously tax audits which measure is to contribute to effective tax administration in accordance with the OECD standards in the entire territory of the Customs Union. 